\title{
BIOPESTICIDES THE SUSTAINABLE WAY OF ORGANIC AND HEALTHY TOMATO PRODUCTION
}

\author{
Pölös Endre ${ }^{1^{*}}$, Szabó Csaba ${ }^{2}$, Palkovics András ${ }^{2}$, Fernanda Delgado ${ }^{3,4}$ \\ ${ }^{1}$ Department of Agricultural Sciences, Faculty of Horticulture and Rural Development, John von \\ Neumann University, Hungary \\ ${ }^{2}$ Department of Agroeconomy and Rural Development, Faculty of Horticulture and Rural \\ Development, John von Neumann University, Hungary \\ ${ }^{3}$ Polytechnic Institute of Castelo Branco-School of Agriculture, Portugal \\ ${ }^{4}$ CERNAS-IPCB- Research Centre for Natural Resources, Environment and Society, Instituto \\ Politécnico de Castelo Branco, Portugal \\ https://doi.org/10.47833/2020.3.AGR.005
}

\section{Keywords \\ biological plant protection \\ allelopathy \\ bioherbicide \\ essential oils \\ repellents effect}

\section{Article history: \\ Received 12 Nov 2020 \\ Revised 20 Nov 2020 \\ Accepted 25 Nov 2020}

\begin{abstract}
In our experiment, we used allelochemicals in vegetable production that can be incorporated in part or in whole into integrated pest management or in organic production. The plant extracts we used can be applied to the crop in the same way as conventional pesticides. Correlations can be found between the allelochemicals that we used in plant protection, the positive change in the average yield, the reduction of harmful organisms and the health status of the cultivated plants. Bioherbicide has been shown to be an effective weed control containing allelochemicals that inhibit photosynthesis.

Extracts of extremely hot chili pepper (Capsicum annuum ssp.) varieties, aqueous solutions of essential oils of herbs and spices were used for plant protection in tomato plantations under open field conditions. The results show that chili pepper extract is a strong repellent, and lavender (Lavandula angustifolia) essential oil solution has a repellent, fungicidal and bactericidal effect at the same time.
\end{abstract}

\section{Introduction}

The use of the agrochemicals increasing vegetable productivity, but they cause adverse effects on soil, water quality, produce quality and developed problems like insect resistance, genetic variation in plants and toxic residues on vegetable food.

In our research, we would like to prove that the use of allelochemicals can be a nature-friendly method that can be incorporated into horticultural plant protection, and, also, contributed to point out that It is important to protect ourselves against pests and pathogens in an environmentally friendly way. Biopesticide is one of the promising alternatives to manage environmental pollution.

Monitoring and evaluation research is essential to better understand the effects of allelopathic drugs. We need to change our approach in order to release less chemical pesticides into our environment, which can have a detrimental effect on human health and nature. It is important to protect ourselves against pests and pathogens in an environmentally friendly way. In the case of open field tomatoes (Lycopersicon lycopersicum), during traditional cultivation, it is necessary to apply a pesticide treatment 16 times at least in the production cycle [2], during which approx. stock spraying with 8-10 different synthetic active ingredients is required.

\footnotetext{
* Corresponding author. Tel.: +36 76517661

E-mail address: polos.endre@kvk.uni-neumann.hu
} 
Allelopathic plant active ingredients [4, 5] are mostly contained in herbs and spices [1, 3] (e.g. terpenoids), which usually have a beneficial effect on our health. They generally have antifeedant or antimicrobial effects on pathogens, as well as repellents. Rapid degradation (e.g. photopesticides) and evaporation are typical for them and they do not accumulate in the environment. In our research we examined plant active ingredients. We particularly focused on the repellent, bactericidal and fungicidal complex lavender essential oil (Lavandulae aetheroleum), the repellent chili pepper extract and the highly effective bioherbicide in tomato production. We investigated the practical applicability of these natural active ingredients in plant protection and the possible inhibitory factors that need to be addressed.

\section{Materials and methods}

\section{Biopesticides:}

1) Lavandula angustifolia Lavender officinalis $100 \%$ essential oil (Lavandulae aetheroleum), a white, opaque emulsion shaken with water using a detergent (potash soap) (Fig. 1), which, after standing for 6 hours, separates into fractions of water and essential oil floating on top.

2) Extract of two types of chili peppers (Capsicum annuum 'Habanero') and (C. annuum 'Carolina reaper') with 1:1 ratio in $60 \%$ ethyl alcohol + potassium soap (Fig. 2), which extract does not need to be diluted before application.

3) A self-made bioherbicide, which is a plant extract containing photosynthesis-inhibiting allelochemicals (naphthoquinone derivatives). The exact composition of it is still in secrecy and under study so we will not be able to reveal its composition at this stage of the investigation (Fig. 3); it is a greenish brown emulsion with little foam on top.

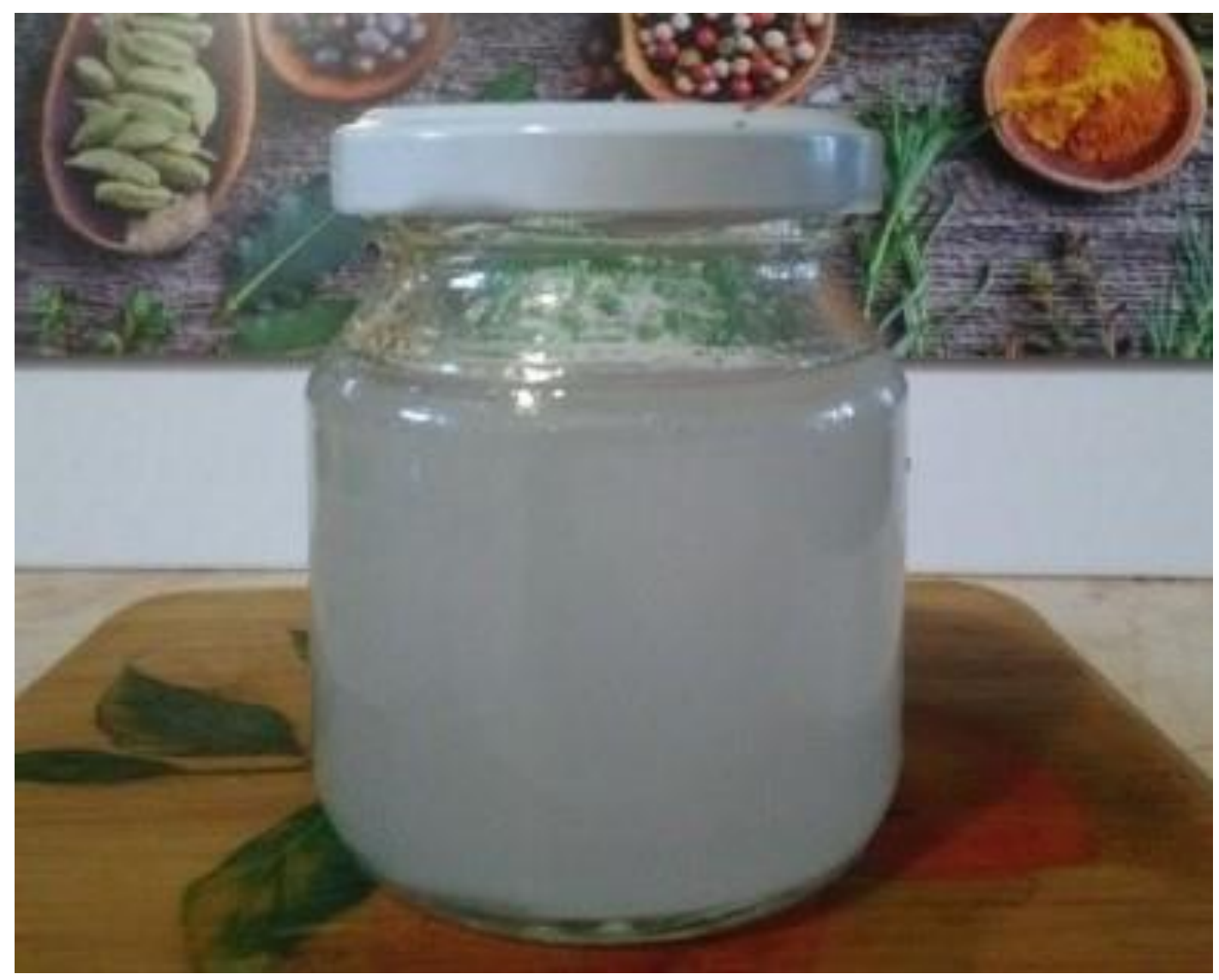

Figure 1. Lavender solution 


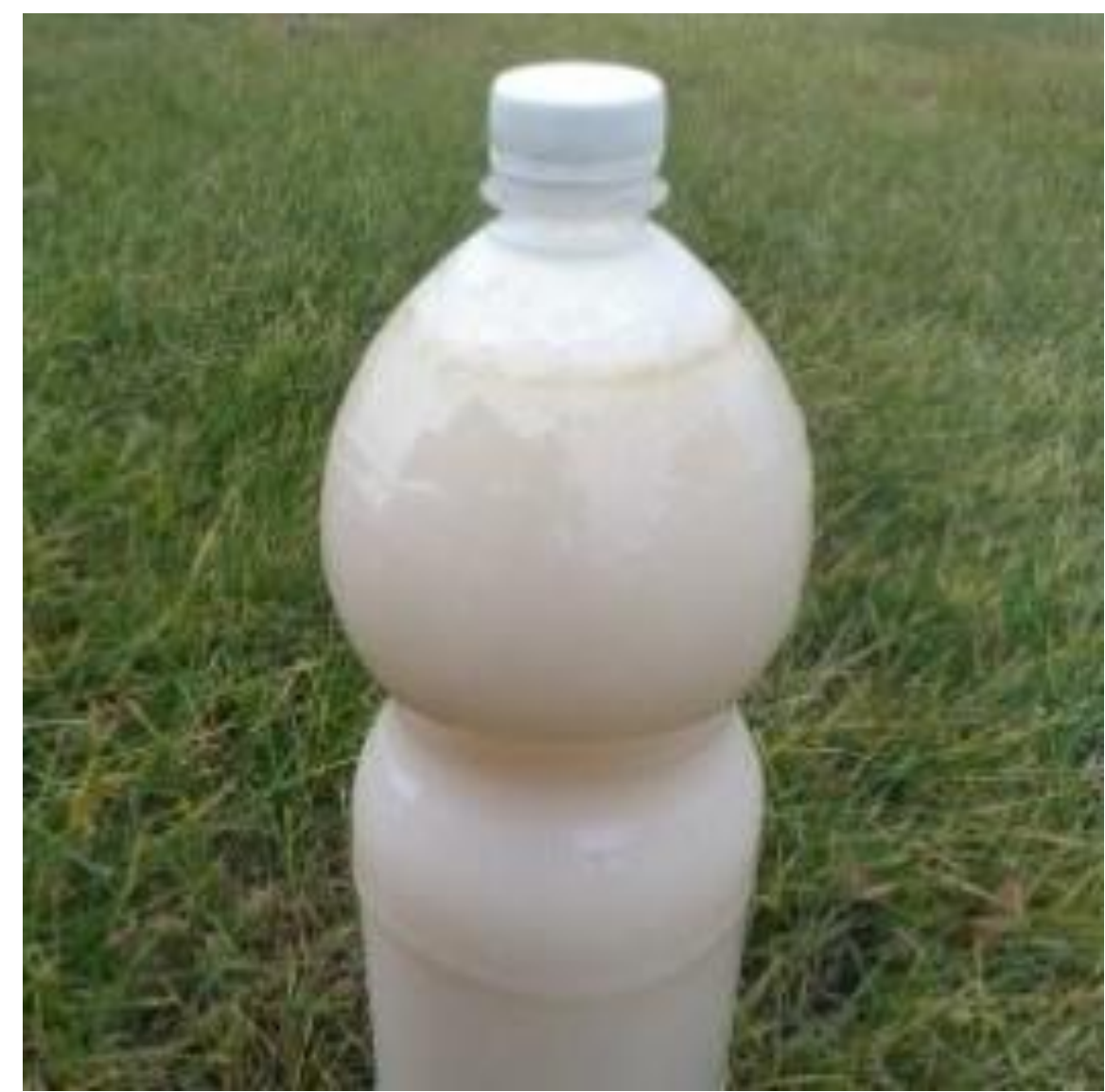

Figure 2. Chili extract

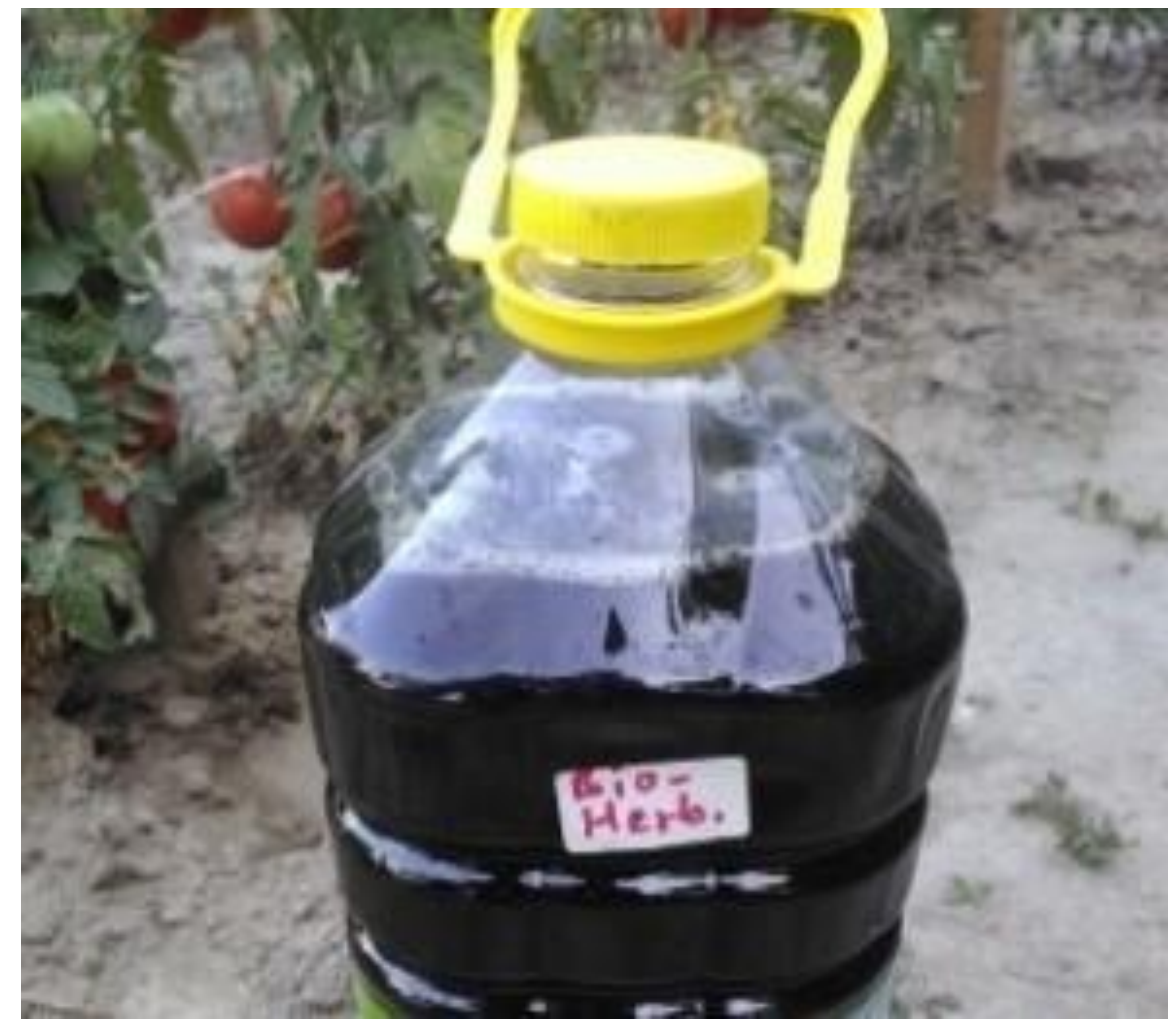

Figure 3. Bioherbicide 
The size of the small plot experimental area is $32 \mathrm{~m}^{2}$. The support system is made of wooden columns and steel wire. The rows were formed in the direction of the width of the area. The area is $4 \mathrm{~m}$ wide and $8 \mathrm{~m}$ long.

Row spacing: $120 \mathrm{~cm}$

Planting distance: $40 \mathrm{~cm}$.

Growing area: $0.48 \mathrm{~m}^{2}$

On the $32 \mathrm{~m}^{2}$ experimental area, 40 plants of continuously ripening tomato were planted on May 10, and stem-holding clips were used to fix the plants (Fig. 4.).

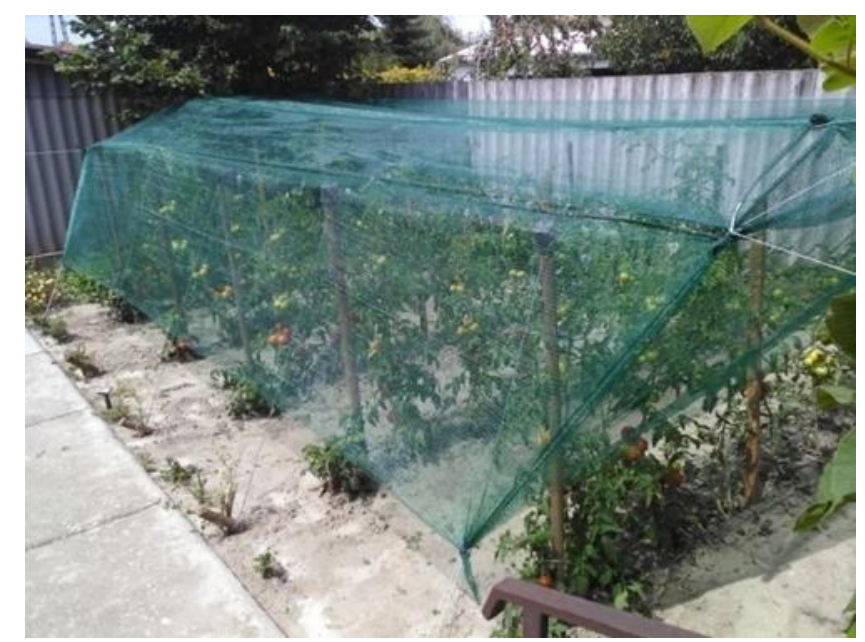

Figure 4. Growing tomato plantation experiment with a shading net that can be rolled up

In the experimental area, after the planting, the plants were treated once a week until the end of August with lavender essential oil and Chili pepper extract. In combination with the two agents, we treated the tomato plants six times every two weeks. Besides this, there were treatments eight times with the lavender essential oil emulsion alone, and twice with the chili pepper extract alone. The experimental area was treated three times with bioherbicide in the first week of June, July and August. The allelochemical treatments used in the experimental area are shown in Table 1.

Table 1. Allelopathic pesticides applied in outdoor tomato plantations in ripening

\begin{tabular}{|c|c|c|}
\hline Pesticide & Agent & Number of treatments \\
\hline \multirow{2}{*}{$\begin{array}{l}\text { Lavender essential oil } 0.2 \% \\
\text { solution }\end{array}$} & \multirow{2}{*}{$\begin{array}{l}\text { linalool, linalyl acetate, } \\
\text { essential oil components }\end{array}$} & 8 \\
\hline & & $\begin{array}{l}+6 \text { cases lavender and } \\
\text { chili together ( } 1: 1 \text { ratio) }\end{array}$ \\
\hline \multirow[t]{2}{*}{ Chili extract } & \multirow[t]{2}{*}{$\begin{array}{l}60 \% \text { alcoholic extract of } \\
\text { capsaicin + potassium soap }\end{array}$} & \\
\hline & & 2 \\
\hline Bioherbicide & allelochemicals & 3 \\
\hline$\Sigma$ & - & 19 \\
\hline
\end{tabular}




\section{Results}

Correlations can be found between the use of allelochemicals in plant protection, the positive change in the average yield, the reduction of harmful organisms and the health status of the cultivated plants (Table 2.). The herbicide containing allelochemicals that inhibit bioherbicide photosynthesis has proven to be highly effective, while the natural composition of the bioherbicide is not expected to significantly burden the environment. Extracts of extremely hot chili peppers (Capsicum annuum ssp.) varieties and aqueous solutions of lavender (Lavandula angustifolia) essential oils were used preventively against pathogens and pests for plant protection in tomato plantations. According to the results, chili pepper extract is a strong repellent, and the lavender (Lavandula angustifolia) essential oil solution can have repellent, fungicidal, bactericidal effect at the same time. The applied allelochemical plant protection experimental methods show, that compared to the untreated plant control groups, the allelopathic active substances produce a measurable positive result in terms of both the increase in the average yield and the increase in the number of healthy crops.

Table 2. Distribution of average yield of experimental tomato plantations by allelochemical-treated and untreated methods

\begin{tabular}{|c|c|c|c|c|}
\hline${ }_{\text {Area }}$ & $\begin{array}{l}\text { healthy } \\
\text { berries }\end{array}$ & $\begin{array}{l}\text { berries } \\
\text { affected by } \\
\text { pests }\end{array}$ & $\begin{array}{l}\text { berries } \\
\text { affected by } \\
\text { pathogens }\end{array}$ & $\begin{array}{c}\text { total } \\
\text { yield } / \mathrm{m}^{2}\end{array}$ \\
\hline Treated plants $\mathrm{kg} / \mathrm{m}^{2}$ yield & 7.8 & 0.3 & 0.3 & $8.4 \mathrm{~kg}$ \\
\hline Untreated plants $\mathrm{kg} / \mathrm{m}^{2}$ yield & 6.0 & 0.7 & 0.7 & $7.4 \mathrm{~kg}$ \\
\hline
\end{tabular}

In the experimental tomato plantation, bioherbicide was applied in two rows to weed control. Two control rows were not treated with herbicide, only mechanical weeding was performed after the test. Weeds treated with bioherbicide already showed the first signs of wilting after 12 hours, and after 20 hours they clearly showed the effect of bioherbicide. Their photosynthesis was reduced to such an extent that the cells were irreversibly damaged as a result and the plants were killed (Fig. $5-6)$.
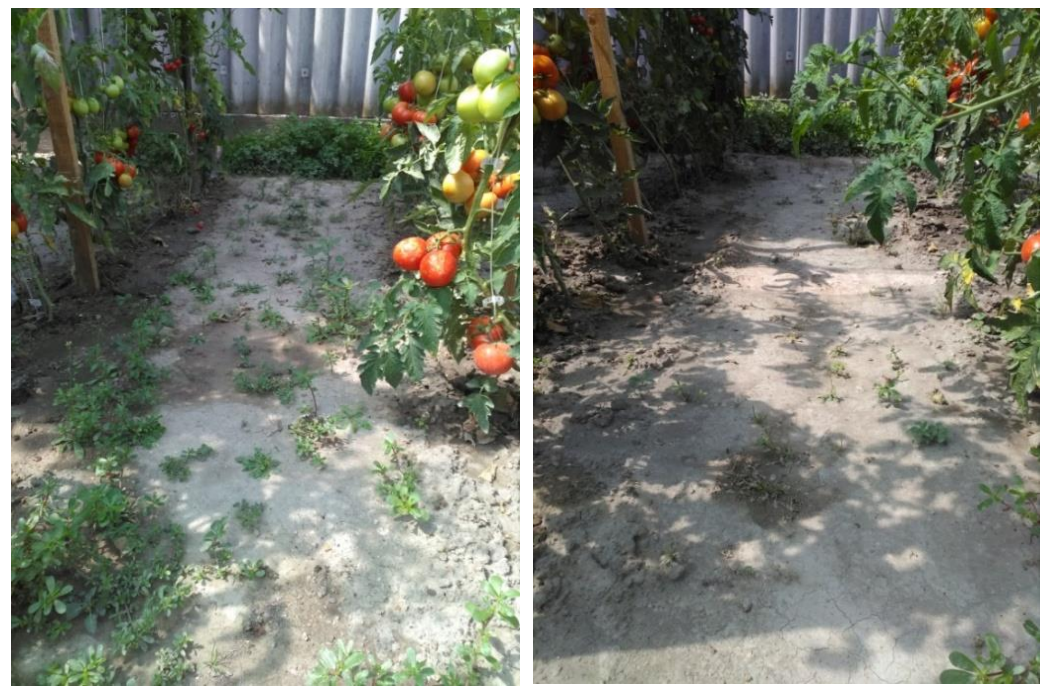

Figure 5-6. Untreated row spacing on the left, bioherbicide-treated row spacing on the right with dried weeds 


\section{Conclusions}

Natural plant extracts can be incorporated into integrated pest management or serve as a basis for a new type of pesticide. With much research, a complete, comprehensive allelochemical plant protection could be assembled into an integrated plant protection in a given plantation. Chili pepper extract is repellent and insecticidal, and the bioherbicide has an excellent weed control effect. Experiments have shown that lavender essential oil solution is insecticidal at a concentration of 2$4 \% \mathrm{v} / \mathrm{v}$, but at this concentration it cannot be used for plant protection because it also damages plant tissues and the leaves turn brown. In the fight against pathogenic fungi in tomato cultivation, lavender essential oil proved to be the widest spectrum of action among the allelopathic natural essential oils. It means, that in addition to its repellent effect (e.g. Aulacortum solani), lavender essential oil also has fungicidal (e.g. Leveillula taurica) properties.

\section{Acknowledgment}

Thank you for the support of EFOP-3.6.2-16-2017-00012 "Development of a product chain model for functional, healthy and safe foods from farm to fork based on a thematic research network" project. This project is supported by the Hungarian State and the European Union, co-financed by the European Social Fund, under the Széchenyi 2020 program.

\section{References}

[1] Biegelbauer P. (2012): Gyógyító illatok - Aromaterápia, Bioenergetic Kiadó, Budapest, p. 82., pp. 24-25.

[2] Hodossi S., Kovács A., Terbe I. (2009): Zöldségtermesztés szabadföldön, Mezőgazda Kiadó, Budapest, p. 69., 74., 117., pp. 133-144.

[3] Rácz G., Rácz-Kotilla E., Szabó L. Gy. (2012): Gyógynövények ismerete - A fitoterápia és az alkalmazott medicina alapjai, Galaneus Kiadó, Budapest, p.53, 62., pp.386-387.

[4] Rice, E. L. (1974): Allelopathy, Academic Press Inc., New York, p. 353. https://doi.org/10.1016/B978-0-12-587050-4.50013-3

[5] Szabó L. Gy. (1997): Allelopathi Phytochemical Potential-Life strategy, (Janus Pannonius Tudományegyetem Növénytani Tanszék és Botanikus Kert), Bornus Nyomdaipari Szolgáltató Kft., Pécs, p. 41., 71., pp. 111-116. 